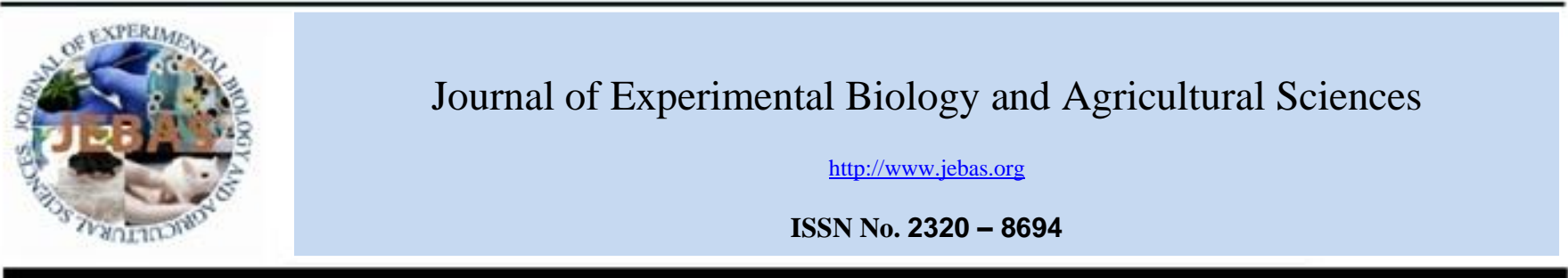

\title{
Evaluations of Morpho-Physiological Variances in Soybean Varieties under Low Water Conditions
}

\section{Phetole Mangena*, Paseka Tritieth Mabulwana}

Department of Biodiversity, School of Molecular and Life Sciences, Faculty of Science and Agriculture, University of Limpopo, Private Bag X1106, Sovenga, 0727, Republic of South Africa

Received - August 09, 2021; Revision - November 09, 2021; Accepted - January 12, 2022

Available Online - February 28, 2022

DOI: http://dx.doi.org/10.18006/2022.10(1).12.20

KEYWORDS
Antioxidant activity
Chlorophyll
Flavonoid content
Phenolics
Soybean
Water-deficit stress

\begin{abstract}
This study used pot experiments with a completely randomized design (CRD) in triplicates to evaluate physiological and morphological attributes used for the characterization of drought stress tolerance in six soybean varieties (Knap, Mopani, LS677, LS678, Pan1564, and Sonop). Growth and physiological parameters analyzed in this study, included plant height, number of flowers, number of pods, seed number per pod, leaf surface area (LSA), grain yield, and total phenolics, flavonoids, ureides as well as antioxidant activity. Low water conditions caused varied negative effects depending on the level of stress on both morphological and physiological responses of the plants. Enhanced secondary products (ureides, total phenolic, and flavonoid content) were observed in plants subjected to severe water stress, in addition to reduced photosynthetic components and percentage grain yields. However, soybean variety Sonop, LS677, and LS678 consecutively, induced high secondary metabolite accumulations and antioxidant activity possibly preventing the occurrence of excessive oxidative stress damage caused by water shortage. The performance of LS varieties, Knap and Sonop were more prominent than Mopani and Pan1564. Results showed potential tolerance to stress in Sonop, LS678 and LS677, attributed to the strong free radical scavenging activity and maintenance of photosynthetic pigments used to achieve sufficient growth balance in plants.
\end{abstract}

* Corresponding author

E-mail: Phetole.Mangena@ul.ac.za; mangena.phetole@gmail.com (Phetole Mangena)

Peer review under responsibility of Journal of Experimental Biology and Agricultural Sciences.

Production and Hosting by Horizon Publisher India [HPI] (http://www.horizonpublisherindia.in/).

All rights reserved.
All the articles published by Journal of Experimental Biology and Agricultural Sciences are licensed under a Creative Commons Attribution-NonCommercial 4.0 International License Based on a work at www.jebas.org.

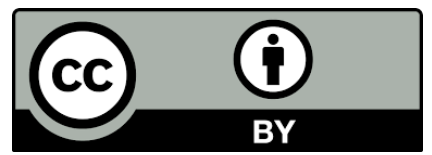




\section{Introduction}

Soybean (Glycine max L. Merr.) has been serving as a stable crop for generations and is currently exploited as an industrial crop for applications such as bio-oil extraction and processing, manufacturing of pharmaceuticals, as well as nutraceutical products (Mangena 2021). The above-mentioned attributes and benefits continue to sustain commercial cultivation of soybean as a major alternative source of oils and proteins, further encouraging the acquisition of new and improved genetic traits to enhance plant growth and productivity. To date, the main challenge facing this crop has been the susceptibility of many genotypes to harsh environmental conditions such as water shortage (drought), chilling stress, poor germplasm, and the rapidly diminishing quality of seeds (Hussain et al. 2019). Drought, in particular, is a major problem in soybean agriculture wherein the crop remains highly sensitive to water-deficit stress than any kind of abiotic stress. In 2019/20 projections, the production of soybean in sub-Saharan African countries was averaged at 1.235 compared to 1.366 and 2.865 metric tons per hectare for Latin America and East-West Asia, respectively. Reductions recorded in sub-Saharan Africa were due to the frequent acute droughts experienced by the region since 2019 (Engelbrecht et al. 2020). Thus, genotype characterization for selection of stressresistant properties and breeding of newly improved cultivars, including the conservation of superior genotypes, are available means for up-keeping crops adaptability to conditions disposed to biotic and abiotic stress factors. Drought (also known as water-deficit stress) is one of the most important environmental pressures capable of causing massive reductions in plant growth and development Drought stress leads to significant decreases of more than $50 \%$ losses in crop yield for many species worldwide (Mohamed and Latif 2017). Drought-triggers abscission of leaves, flowers, fruits, and other plant organs, causing morphological and biochemical differentiation and defects in affected tissues. Abscission serves as a mechanism for stress resistance or a marker of severe exposure to abiotic stress (You and Chan 2015). For example, leaf abscission regulated by the interaction of ethylene and auxin is used by biennial and perennial plants to regulate water loss and maintain balanced water levels within tissues (Patharkar and Walker 2016). Death of the whole plant can also occur due to accelerated senescence of tissues in plants exposed to severe water-deficit stress. Furthermore, the physiological influence of abiotic stress needs to be determined, particularly concerning soybean growth and productivity. The anabolic and catabolic processes involving primary metabolites are used by the plants to yield energy required for growth and reproductive activities. However, drought stress triggers major physiological and metabolic changes including reduced photosynthetic pigments, fluctuating amounts of secondary products (ureides, phenolic, and flavonoid contents, etc.), and accumulation of harmful by-products like reactive oxygen species (ROS) (Evert and Eichhorn 2013; You and Chan 2015). This stress subsequently causes adverse effects on plant metabolism by inhibiting the synthesis and utilization of sugars by the source and sink tissues. All metabolic alterations, including morphological growth of soybean plants exposed to drought stress, could provide insights on how a range of adaptations to different stress levels could assist plants in withstanding stressful conditions. This study, therefore, evaluated the physiological and morphological attributes of different soybean varieties for the characterization of these genotypes to identify those showing tolerance against water-deficit stress.

\section{Materials \& Methods}

\subsection{Plant materials and study location}

Soybean (G. max.) varieties (Mopani, Knap, LS677, LS678, Pan1564, and Sonop) were used in this study. The varieties were sourced from the Agricultural Research Council (ARC), Tshwane in South Africa, and evaluated for drought stress tolerance at the University of Limpopo (Sovenga, Turfloop campus), Capricorn District in the Limpopo Province $\left(23.8888^{\circ} \mathrm{S}, 29.7386^{\circ} \mathrm{E}\right)$.

\subsection{Plant establishment and water stress treatment}

Seeds were grown in $35 \mathrm{~cm}$ plastic pots containing vermiculite (Greener Tidings Garden Centre, Polokwane, South Africa) in a greenhouse using a randomized block design. For germination and plant establishment, sown seeds were watered twice a week with half-strength Hoagland solution prepared as described by Taiz et al. (2015) and daily with distilled water depending on the moisture content of the medium until they reached Vegetative Growth Stage three (V3). Water-deficit stress was then imposed on the soybean plants by watering once in 5 days to achieve moderate drought stress and once in 7 days for severe drought stress for 3-9 weeks (Mangena 2020a). Soybean plants used as a control were watered daily to saturation depending on the vermiculite moisture. Moisture levels were measured using a Ryobi moisture meter MM210 (Ryobi, Africa, Midrand, South Africa). Water stress treatments were then terminated after 4-9 weeks when plants reached Reproductive Growth Stage three (R3). Data was recorded in triplicates for both control and water stress-treated plants.

\subsection{Morphological data}

Plant height was measured from the tip of the plant to the base of the stem just above the level of vermiculite. A metric fluorescent ruler $(1 \mathrm{~m})$ (Sigma Aldrich, South Africa) was used to measure the heights of soybean plants. The number of flowers, pods, and seeds per pod produced were countered directly from each plant in all the treatments and control. Leaf surface area (LSA) was estimated from the three leaf samples per plant in triplicates, traced, weighed, and calculated using the formula as indicated below (Campillo et al. 2010). 


\section{Calculating formula:}

$$
\text { LSA }=\frac{25.00 \mathrm{~cm}^{2} \times \text { mass of leaf trace }}{\text { mass of } 25.00 \text { paper }\left(\mathrm{cm}^{2}\right)}
$$

\subsection{Relative leaf water content}

A total of three middle leaflets of trifoliate leaves per plant were detached and immediately weighed to determine fresh weight. The leaflets were completely immersed in distilled water for 24 hours. After this period, the leaflets were blotted dry using a clean paper towel and then re-weighed to determine the saturated weight. Leaflets were then dried at $60^{\circ} \mathrm{C}$ in an oven for 24 hours and reweighed until a constant dry weight was achieved. The below formula was then used to calculate the leaf relative water content (RLWC) where $F m$ refers to the fresh weight, $S w$ refers to the saturated mass of leaf samples, and $D m$ to the dry weight of the leaflet samples (Soltys-Kalina et al. 2016).

\section{Calculating formula:}

$$
\text { RLWC }=\frac{F w-D w}{S w-D w}
$$

\subsection{Physiological data}

Leaflet samples per plant were harvested and immediately homogenized in liquid nitrogen and stored at $-86^{\circ} \mathrm{C}$ until used for the determination of total phenolics, total flavonoids, ureides content, and antioxidant activity.

\subsubsection{Total phenolics}

Total phenolics in harvested leaflets was determined spectrophotometrically using the Folin-Ciocalteau method as described by Torre et al. (1987). A $100 \mathrm{mg}$ frozen powder for each treatment was extracted with $15 \mathrm{~mL}$ methanol in $150 \mathrm{~mL}$ Erlenmeyer flask on an OrbiShake Platform Shaker (LABOTEC, Midrand, South Africa) for two hours. The extracted plant materials were then filtered into $50 \mathrm{~mL}$ volumetric flasks using a coned Whatman No. 1 filter paper (Lasec Group, Johannesburg, RSA). The residues were washed a few times with methanol and the extract volume made up to $50 \mathrm{~mL}$ using the methanol. A 500 $\mu \mathrm{L}$ of each extract was thoroughly mixed with $0.5 \mathrm{~mL}$ FolinCiocalteau (Sigma-Aldrich, Johannesburg, South Africa) in $5 \mathrm{~mL}$ distilled water and then allowed to stand for 5 minutes at room temperature. A $1.5 \mathrm{~mL}$ of $20 \%$ sodium carbonate was added to the extracts, made up to $50 \mathrm{~mL}$ with distilled water, mixed, and incubated at $50{ }^{\circ} \mathrm{C}$ for another two hours. The mixture was vortexed, and absorbance was read at $765 \mathrm{~nm}$ using a Jenway UVVisible Spectrophotometer (Jenway, Asia Cole-Parmer, China). Total phenolics $(P T)$ of the extract was calculated as gallic acid equivalents. The formula below, where $c$ - is the concentration of gallic acid in $\mu \mathrm{g} / \mathrm{mL}, V$ - volume of extract in $\mathrm{mL}$, and $m$ - is the weight (mg) of the extract was used.

Calculating formula:

$$
\mathrm{PT}=\mathrm{c} \frac{\mathrm{V}}{\mathrm{m}}
$$

\subsubsection{Total flavonoids}

Total flavonoid contents was determined according to the procedure by Zhishen et al. (1999) and Marinova et al. (2005). Aliquots of $500 \mu \mathrm{L}$ of the extracts were thoroughly mixed with 2 $\mathrm{mL}$ distilled water and $1.5 \mathrm{~mL}$ of $5 \%$ sodium nitrate (Rochelle Chemicals, Johannesburg, RSA). The mixtures was incubated for 5 minutes at room temperature and $0.15 \mathrm{~mL}$ of $10 \%$ aluminum chloride (Rochelle Chemicals, Johannesburg, RSA) was added to each extract and incubated again under room temperature for 6 minutes. After incubation, $1 \mathrm{~mL}$ of $1 \mathrm{M}$ sodium hydroxide was added to the extract and made up to $10 \mathrm{~mL}$ volume with distilled water and the absorbance read at $510 \mathrm{~nm}$ using a Jenway UVVisible Spectrophotometer (Jenway, Asia Cole-Parmer, China). Total flavonoid $(T F)$ contents of the extract was determined as catechin equivalents, calculated as indicated below where; $A s$ - is the absorbance of extract, $A c$ - is the standard catechin absorbance, $M c$ - is the weight of extract, and $M s$-is the weight of catechin.

\section{Calculating formula:}

$$
\mathrm{TF}=\frac{\mathrm{As} \times \mathrm{Mc}}{\mathrm{Ac} \times \mathrm{Ms}}
$$

\subsubsection{Extraction and determination of ureides}

Ureides (allantoin and allantoic) were extracted using $0.2 \mathrm{M} \mathrm{NaOH}$ as described by van Heerden et al. (2008). Samples of ground leaf powders were boiled in $1 \mathrm{~mL} \mathrm{NaOH}$ to convert allantoin to allantoic acids for 20 minutes. The mixture was cooled on ice for $10-15$ minutes, centrifuged at $10,000 \times x$ for 10 minutes and $350 \mu \mathrm{L}$ distilled water was added to $50 \mu \mathrm{L}$ of the extracts. Ureide contents were then determined by reading the absorbance at $525 \mathrm{~nm}$ and using allantoin standards as indicated by van Heerden et al. (2008).

\subsubsection{Antioxidant assay}

The antioxidant activity was determined using a 2.2-Diphenyl-1picrylhydrazyl (DPPH) method as described by Odhav et al. (2007). About $2.5 \mathrm{~mL}$ of plant extracts were thoroughly mixed with $1 \mathrm{~mL}$ of $0.3 \mathrm{mM}$ DPPH in $2.5 \mathrm{~mL}$ methanol. The mixture was then incubated for 30 minutes at room temperature, followed by an absorbance reading at $518 \mathrm{~nm}$ using the Jenway Spectrophotometer. Percentage DPPH scavenging activity was calculated using the formula below, where $A D$ is the absorbance 
value at $518 \mathrm{~nm}$ of methanolic DPPH solution and $A S$ refers to the absorbance value at $518 \mathrm{~nm}$ for the sample extract.

\section{Calculating formula:}

$$
\text { DPPH Scavenging activity }=\frac{\mathrm{AD}-\mathrm{AS}}{\mathrm{AD}} \times 100
$$

\subsubsection{Statistical Analysis}

The experiment was conducted in triplicates and repeated thrice. All data was subjected to variation analysis using SPSS statistics program version 26 analysis of variance (ANOVA). The t-test was performed to determine the level of significant differences between means at $5 \%$ confidence level.

\section{Results \& Discussion}

3.1 Morphological and reproductive response of plants to water-deficit stress

As indicated in Table 1-3, plant heights were measured based on stem heights determined using a metric ruler. According to the results, water-deficit stress affected soybean growth by decreasing the lengths of stems during moderate (Table 2) and severe (Table 3) water-deficit stress as compared to the control (Table 1). The tallest stems were observed in LS678 in the control, and the shortest was recorded by Pan1564 plants under severe water stress. On average, stem lengths were decreased by at least $5 \%$ under moderate stress compared to $15.4 \%$ in plants subjected to severe

Table 1 Summary of results on morphological parameters analysed in well-watered soybean plants

\begin{tabular}{|cccccc|}
\hline Varieties & Plant Height & No. of Flowers/ Plant & No. of Pod/Plant & Seeds/pods & LSA \\
\hline Knap & $39.2 \pm 0.42^{\mathrm{a}}$ & $10.0 \pm 0.00^{\mathrm{a}}$ & $22.2 \pm 0.32^{\mathrm{a}}$ & $3.0^{\mathrm{a}}$ & $42.0 \pm 0.36^{\mathrm{a}}$ \\
\hline Mopani & $33.2 \pm 0.35^{\mathrm{b}}$ & $9.0 \pm 2.82^{\mathrm{b}}$ & $31.6 \pm 0.20^{\mathrm{b}}$ & $3.0^{\mathrm{a}}$ & $114.0 \pm 2.14^{\mathrm{b}}$ \\
\hline LS677 & $32.5 \pm 0.28^{\mathrm{c}}$ & $8.0 \pm 2.12^{\mathrm{c}}$ & $24.4 \pm 0.28^{\mathrm{c}}$ & $3.0^{\mathrm{a}}$ & $45.0 \pm 3.14^{\mathrm{c}}$ \\
\hline LS678 & $50.1 \pm 0.56^{\mathrm{d}}$ & $10.0 \pm 2.12^{\mathrm{d}, \mathrm{a}}$ & $31.3 \pm 0.20^{\mathrm{d}, \mathrm{b}}$ & $3.0^{\mathrm{a}}$ & $38.0 \pm 1.36^{\mathrm{d}}$ \\
\hline Pan1564 & $23.4 \pm 0.28^{\mathrm{e}}$ & $10.0 \pm 0.0^{\mathrm{e}, \mathrm{d}, \mathrm{a}}$ & $34.0 \pm 0.21^{\mathrm{e}}$ & $3.0^{\mathrm{a}}$ & $46.0 \pm 3.88^{\mathrm{e}}$ \\
\hline Sonop & $40.3 \pm 0.28^{\mathrm{f}}$ & $9.0 \pm 0.70^{\mathrm{f}, \mathrm{b}}$ & $25.6 \pm 0.27^{\mathrm{f}}$ & $3.0^{\mathrm{a}}$ & $49.0 \pm 0.56^{\mathrm{f}}$ \\
\hline
\end{tabular}

Different superscript letters within columns indicate statistical significance using ANOVA (t-test) where p-value $<0.05$ and values with similar letters are not statistically different at the same p-value.

Table 2 Results on morphological evaluation of soybean plants subjected to moderate water-deficit stress

\begin{tabular}{|cccccc|}
\hline Varieties & Plant Height & No. of Flowers/ Plant & No. of Pod/ Plant & Seeds/pods & LSA \\
\hline Knap & $36.6 \pm 0.14^{\mathrm{a}}$ & $8.0 \pm 0.00^{\mathrm{a}}$ & $13.0 \pm 0.23^{\mathrm{a}}$ & $3.0^{\mathrm{a}}$ & $29.0 \pm 2.81^{\mathrm{a}}$ \\
\hline Mopani & $32.1 \pm 0.21^{\mathrm{b}}$ & $8.0 \pm 0.70^{\mathrm{a}}$ & $18.1 \pm 0.01^{\mathrm{b}}$ & $2.0^{\mathrm{b}}$ & $66.0 \pm 0.81^{\mathrm{b}}$ \\
\hline LS677 & $31.6 \pm 0.28^{\mathrm{c}}$ & $8.0 \pm 2.12^{\mathrm{a}}$ & $17.4 \pm 0.02^{\mathrm{c}}$ & $3.0^{\mathrm{c}}$ & $36.0 \pm 0.72^{\mathrm{c}}$ \\
\hline LS678 & $39.2 \pm 0.28^{\mathrm{d}}$ & $8.0 \pm 2.12^{\mathrm{a}}$ & $22.4 \pm 0.14^{\mathrm{d}}$ & $3.0^{\mathrm{c}}$ & $25.0 \pm 0.17^{\mathrm{d}}$ \\
\hline Pan1564 & $22.1 \pm 0.14^{\mathrm{e}}$ & $9.0 \pm 4.24^{\mathrm{b}}$ & $26.3 \pm 0.03^{\mathrm{e}}$ & $3.0^{\mathrm{c}}$ & $29.0 \pm 2.81^{\mathrm{e}, \mathrm{a}}$ \\
\hline Sonop & $37.2 \pm 0.07^{\mathrm{f}}$ & $6.0 \pm 0.70^{\mathrm{c}}$ & $12.1 \pm 0.11^{\mathrm{f}}$ & $3.0^{\mathrm{c}}$ & $38.0 \pm 3.81^{\mathrm{f}}$ \\
\hline
\end{tabular}

Different superscript letters within columns indicate statistical significance using ANOVA (t-test) where p-value $<0.05$ and values with similar letters are not statistically different at the same p-value.

Table 3 Results on morphological evaluation of soybean plants subjected to severe water-deficit stress

\begin{tabular}{|cccccc|}
\hline Varieties & Plant Height & No. of Flowers/ Plant & No. of Pods/ Plant & Seeds/pod & LSA \\
\hline Knap & $36.6 \pm 0.14^{\mathrm{a}}$ & $6.0 \pm 1.41^{\mathrm{a}}$ & $8.10 \pm 0.10^{\mathrm{a}}$ & $2.0^{\mathrm{a}}$ & $21.0 \pm 0.00^{\mathrm{a}}$ \\
\hline Mopani & $25.8 \pm 0.14^{\mathrm{b}}$ & $6.0 \pm 0.00^{\mathrm{a}}$ & $8.20 \pm 0.30^{\mathrm{a}}$ & $2.0^{\mathrm{a}}$ & $39.0 \pm 1.57^{\mathrm{b}}$ \\
\hline LS677 & $28.3 \pm 0.14^{\mathrm{c}}$ & $6.0 \pm 0.00^{\mathrm{a}}$ & $9.20 \pm 0.05^{\mathrm{b}}$ & $3.0^{\mathrm{b}}$ & $21.0 \pm 0.19^{\mathrm{c}, \mathrm{a}}$ \\
\hline LS678 & $27.3 \pm 0.07^{\mathrm{d}}$ & $7.0 \pm 4.24^{\mathrm{b}}$ & $10.2 \pm 0.20^{\mathrm{c}}$ & $3.0^{\mathrm{b}}$ & $16.0 \pm 3.98^{\mathrm{d}}$ \\
\hline Pan1564 & $21.6 \pm 0.77^{\mathrm{e}}$ & $7.0 \pm 4.24^{\mathrm{b}}$ & $11.6 \pm 0.02^{\mathrm{d}}$ & $3.0^{\mathrm{b}}$ & $10.0 \pm 1.44^{\mathrm{e}}$ \\
\hline Sonop & $35.3 \pm 0.42^{\mathrm{f}}$ & $5.0 \pm 1.41^{\mathrm{c}}$ & $11.2 \pm 0.02^{\mathrm{e}, \mathrm{d}}$ & $3.0^{\mathrm{b}}$ & $19.0 \pm 2 . .40^{\mathrm{f}}$ \\
\hline
\end{tabular}

Different superscript letters within columns indicate statistical significance using ANOVA (t-test) where p-value $<0.05$ and values with similar letters are not statistically different at the same p-value.

Journal of Experimental Biology and Agricultural Sciences http://www.jebas.org 
water-deficit stress. The effects of water stress was more pronounced in LS678 where plant height dropped from $50.1 \mathrm{~cm}$ (Table 1) in the control to $27.3 \mathrm{~cm}$ of plants subjected to severe water deficit stress (Table 3). A similar drop in stem length was also observed in LS677, Mopani, and then Sonop. Soybean variety Pan1564 and Knap recorded slightly constant stem heights throughout the experiment.

Several studies, such as those of Dong et al. (2019), Hussain et al. (2019), and Mangena (2020b) also showed that drought hampers morphological growth by inhibiting stem/ apical growth of shoots, including grain yield (Figure 1) and metabolism related attributes (Figure 2). Hussain et al. (2019) reported a significant reduction in plant height and grain yield following the exposure of maize plants to water-deficit stress. Under all stress treatments, the growth and yield performance of soybean cultivar LS678 and TGx1835-10E were also found to be lowered by drought stress than their controls (Mangena 2020a). Among these parameters, morphology serves as one of the most important indicators of successful plant growth and development, and a measure of growth rate in relation to plant exposure to waterdeficit stress (Dong et al. 2019).

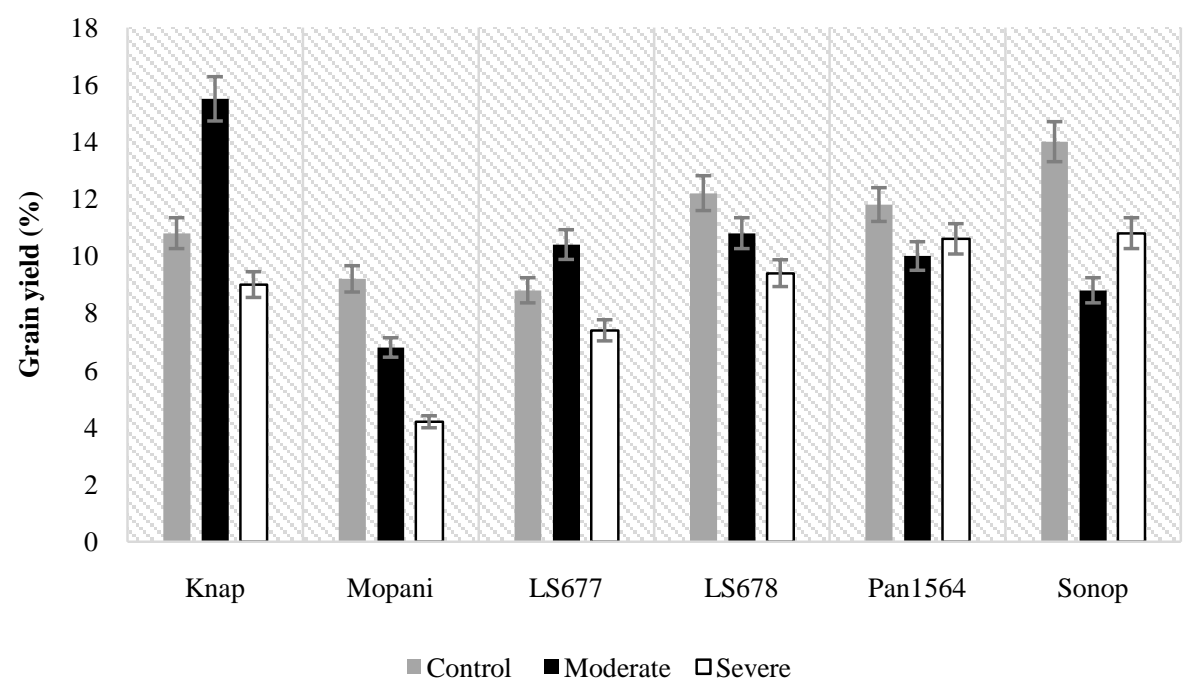

Figure 1 Grain yield of the six soybean varieties analysed at R8 following the exposure of plants to moderate and severe water-deficit stress, as well as well-watered plants used as controls

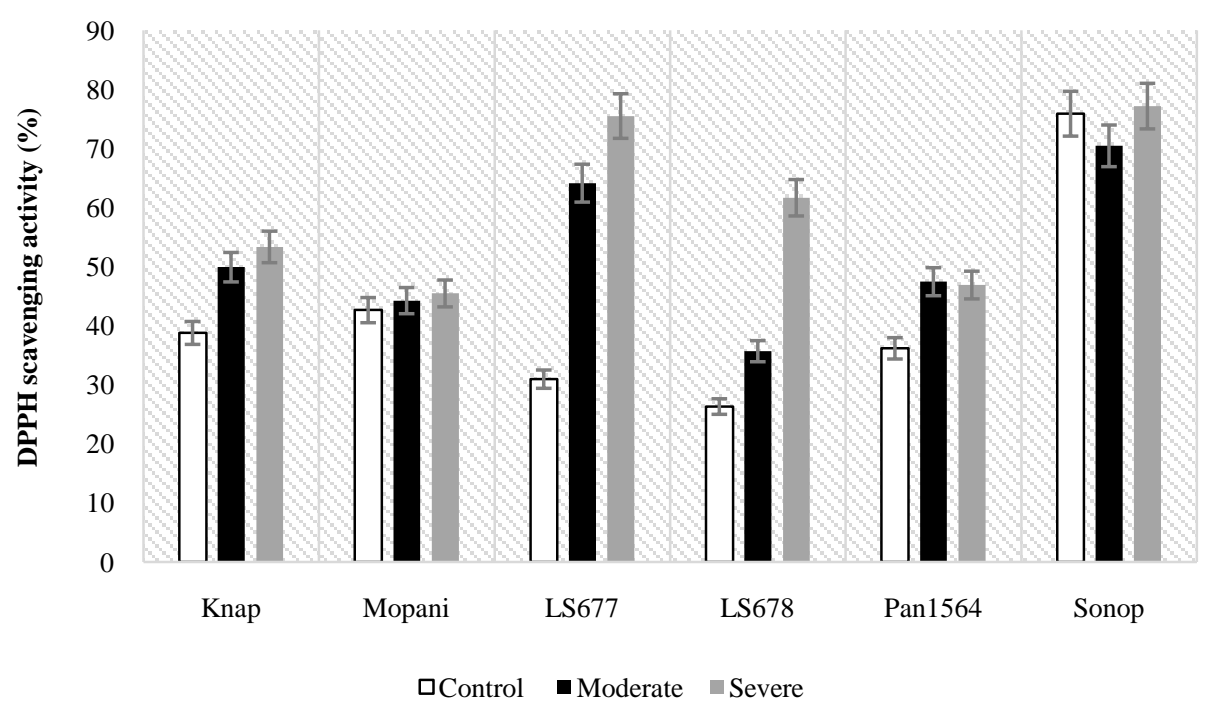

Figure 2 Antioxidant scavenging activity of soybeans analysed after exposure of plants to moderate and severe water deficit stress, and wellwatered plants used as controls 
The decreasing effects were also observed in leaf surface area (LSA), where the highest average surface area $\left(\mathrm{cm}^{2}\right)$ of $114 \mathrm{~cm}^{2}$ in Mopani was reduced to 66 and $39 \mathrm{~cm}^{2}$ under moderate and severe waterdeficit stress, respectively. All other five varieties (Knap, LS677, LS678, Pan1564, and Sonop) also recorded decreasing LSA values with Pan1564 giving the lowest average of LSA $\left(10 \mathrm{~cm}^{2}\right)$. Overall, reduced water levels had negative effects on all parameters as indicated by the above observations. Dong et al. (2019) also indicated how leaf area is positively correlated with the amount of sunlight captured by crops, and therefore, directly affecting photosynthetic rates and grain yields. Observations made in this study demonstrated the effects of induced drought stress and changes, especially on total chlorophyll content of plants exposed to moderate (Table 2) and severe (Table 3) water-deficit stress, as well as plants grown under well-watered control conditions (Table 1). As results show, water-deficit stress inhibited the growth of soybean plants in terms of stem height and leaf area (Table 2 and 3) as the level of stress was prolonged. These inhibitory effects became more significant even on reproductive parameters illustrated in Tables 2 and 3, as well as the overall yield in Figure 1.

Both levels of water stress also reduced the number of flowers, pods, seeds/pod, and grain yield in all six soybean varieties (Table 2 and 3 ). This trend was almost similar to the observation made for the vegetative traits. The highest number of flowers were recorded in
Pan1564 (9.0 \pm 4.24$)$, followed by a total average of 8.0 flowers in both Knap, Mopani, LS677, and LS678, and the lowest being Sonop with an average total of 6 flowers per plant during moderate drought stress. The prolonged exposure of plants to water-deficit stress elevated the reductions by at least $25 \%$ in all varieties and $16 \%$ flower reduction in Sonop alone. The results indicate that all reproductive characteristics were altered or dramatically reduced by imposed water stress. Furthermore, grain yields (Figure 1) were also adversely affected by water shortage due to the physical damage of pods and seeds, physiological and biochemical disruptions, as well as molecular changes that are caused by this abiotic stress (Hussain et al. 2018). However, both morphology and reproductive attributes directly reflected the growth and developmental responses of soybean plants to the induced water-deficit stress.

\subsection{Physiological response of plants to water-deficit stress}

The effect of water-deficit on chlorophyll content (Table 4-6) showed similar trends to those observed for vegetative and reproductive growth parameters (Table 1-3 and Figure 1). The content of photosynthetic pigments was decreased with the decrease in relative leaf water content and also due to the level of water stress (Table 4-6). The reduction in water content of the leaf tissues as indicated in Table 5 and 6 significantly affected the rate of photosynthesis by blocking the transport of energy from

Table 4 Summary of results on physiological parameters analysed in well-watered soybean plants

\begin{tabular}{|ccccccc|} 
Varieties & $\begin{array}{c}\text { Relative Leaf } \\
\text { Water Content }(\%)\end{array}$ & $\begin{array}{c}\text { Total Chlorophyll } \\
(\%)\end{array}$ & $\begin{array}{c}\text { Total Phenolics } \\
(\mu \mathrm{g} / \mathrm{g})\end{array}$ & $\begin{array}{c}\text { Total Flavonoids } \\
(\mu \mathrm{g} / \mathrm{g})\end{array}$ & $\begin{array}{c}\text { Non-flavonoid } \\
\text { phenolics }\end{array}$ & $\begin{array}{c}\text { Leaf Ureides } \\
\text { Content }(\mu \mathrm{g} / \mathrm{g})\end{array}$ \\
\hline Knap & $83.2^{\mathrm{a}}$ & $35.1^{\mathrm{a}}$ & $24.5 \pm 0.14^{\mathrm{a}}$ & $19.9 \pm 0.43^{\mathrm{a}}$ & $4.54 \pm 0.07^{\mathrm{a}}$ & $0.22 \pm 0.39^{\mathrm{a}}$ \\
\hline Mopani & $77.1^{\mathrm{b}}$ & $26.5^{\mathrm{b}}$ & $26.6 \pm 0.08^{\mathrm{b}}$ & $19.1 \pm 0.67^{\mathrm{b}}$ & $7.54 \pm 0.70^{\mathrm{b}}$ & $0.23 \pm 0.09^{\mathrm{a}}$ \\
\hline LS677 & $94.0^{\mathrm{c}}$ & $36.2^{\mathrm{c}}$ & $30.7 \pm 0.02^{\mathrm{c}}$ & $19.6 \pm 0.52^{\mathrm{c}, \mathrm{a}}$ & $11.1 \pm 0.63^{\mathrm{c}}$ & $0.28 \pm 0.12^{\mathrm{b}}$ \\
\hline LS678 & $88.1^{\mathrm{d}}$ & $36.1^{\mathrm{d}, \mathrm{c}}$ & $33.1 \pm 0.03^{\mathrm{d}}$ & $19.8 \pm 0.57^{\mathrm{d}, \mathrm{ac}}$ & $13.2 \pm 0.09^{\mathrm{d}}$ & $0.16 \pm 0.84^{\mathrm{c}}$ \\
\hline Pan1564 & $94.2^{\mathrm{e}, \mathrm{c}}$ & $35.4^{\mathrm{e}}$ & $27.3 \pm 0.06^{\mathrm{e}}$ & $20.8 \pm 0.13^{\mathrm{e}}$ & $6.48 \pm 0.08^{\mathrm{e}}$ & $0.21 \pm 1.02^{\mathrm{d}, \mathrm{a}, \mathrm{b}}$ \\
\hline Sonop & $90.0^{\mathrm{f}}$ & $26.3^{\mathrm{f}, \mathrm{b}, \mathrm{c}}$ & $24.9 \pm 0.07^{\mathrm{f}}$ & $15.5 \pm 0.21^{\mathrm{f}}$ & $9.43 \pm 0.34^{\mathrm{f}}$ & $0.28 \pm 0.51^{\mathrm{d}}$ \\
\hline
\end{tabular}

Different superscript letters within columns indicate statistical significance using ANOVA (t-test) where p-value $<0.05$ and values with similar letters are not statistically different at the same p-value.

Table 5 Summary of results on physiological parameters analysed in soybean plants subjected to moderate water deficit stress

\begin{tabular}{|ccccccc|}
\hline Varieties & $\begin{array}{c}\text { Relative Leaf Water } \\
\text { Content }(\%)\end{array}$ & $\begin{array}{c}\text { Total Chlorophyll } \\
(\%)\end{array}$ & $\begin{array}{c}\text { Total Phenolics } \\
(\mu \mathrm{g} / \mathrm{g})\end{array}$ & $\begin{array}{c}\text { Total Flavonoids } \\
(\mu \mathrm{g} / \mathrm{g})\end{array}$ & $\begin{array}{c}\text { Non-flavonoid } \\
\text { phenolics }\end{array}$ & $\begin{array}{c}\text { Leaf Ureides } \\
\text { Content }(\mu \mathrm{g} / \mathrm{g})\end{array}$ \\
\hline Knap & $69.1^{\mathrm{a}}$ & $30.2^{\mathrm{a}}$ & $46.3 \pm 0.04^{\mathrm{a}}$ & $20.6 \pm 0.70^{\mathrm{a}}$ & $25.6 \pm 0.34^{\mathrm{a}}$ & $0.26 \pm 0.01^{\mathrm{a}}$ \\
\hline Mopani & $74.1^{\mathrm{b}}$ & $23.4^{\mathrm{b}}$ & $24.7 \pm 0.14^{\mathrm{b}}$ & $18.7 \pm 0.09^{\mathrm{b}}$ & $5.99 \pm 0.82^{\mathrm{b}}$ & $0.34 \pm 0.73^{\mathrm{b}}$ \\
\hline LS677 & $80.1^{\mathrm{c}}$ & $33.3^{\mathrm{c}}$ & $48.6 \pm 0.04^{\mathrm{c}}$ & $19.4 \pm 0.33^{\mathrm{c}}$ & $29.1 \pm 0.02^{\mathrm{c}}$ & $0.37 \pm 0.18^{\mathrm{c}, \mathrm{b}}$ \\
\hline LS678 & $88.0^{\mathrm{d}}$ & $30.2^{\mathrm{a}}$ & $64.0 \pm 0.00^{\mathrm{d}}$ & $19.6 \pm 0.03^{\mathrm{d}, \mathrm{c}}$ & $44.3 \pm 0.18^{\mathrm{d}}$ & $0.29 \pm 0.77^{\mathrm{d}, \mathrm{a}, \mathrm{b}, \mathrm{c}}$ \\
\hline Pan1564 & $83.1^{\mathrm{e}}$ & $35.1^{\mathrm{d}}$ & $38.6 \pm 0.03^{\mathrm{e}}$ & $16.4 \pm 0.28^{\mathrm{e}}$ & $22.1 \pm 0.43^{\mathrm{e}}$ & $0.24 \pm 0.21^{\mathrm{e}, \mathrm{a}, \mathrm{b}}$ \\
\hline Sonop & $84.1^{\mathrm{f}}$ & $23.2^{\mathrm{e}, \mathrm{b}}$ & $24.7 \pm 0.02^{\mathrm{f}}$ & $14.8 \pm 0.91^{\mathrm{f}}$ & $9.95 \pm 0.41^{\mathrm{f}}$ & $0.30 \pm 1.52^{\mathrm{f}, \mathrm{a}, \mathrm{c}, \mathrm{d}}$ \\
\hline
\end{tabular}

Different superscript letters within columns indicate statistical significance using ANOVA (t-test) where p-value $<0.05$ and values with similar letters are not statistically different at the same p-value.

Journal of Experimental Biology and Agricultural Sciences

http://www.jebas.org 
Table 6 Summary of results on physiological parameters analysed in soybean plants exposed to severe water-deficit stress

\begin{tabular}{|ccccccc|} 
Varieties & $\begin{array}{c}\text { Relative Leaf Water } \\
\text { Content }(\%)\end{array}$ & $\begin{array}{c}\text { Total Chlorophyll } \\
(\%)\end{array}$ & $\begin{array}{c}\text { Total Phenolics } \\
(\mu \mathrm{g} / \mathrm{g})\end{array}$ & $\begin{array}{c}\text { Total Flavonoids } \\
(\mu \mathrm{g} / \mathrm{g})\end{array}$ & $\begin{array}{c}\text { Non-flavonoid } \\
\text { phenolics }\end{array}$ & $\begin{array}{c}\text { Leaf Ureides } \\
\text { Content }(\mu \mathrm{g} / \mathrm{g})\end{array}$ \\
\hline Knap & $60.0^{\mathrm{a}}$ & $26.3^{\mathrm{a}}$ & $30.5 \pm 0.06^{\mathrm{a}}$ & $20.2 \pm 0.94^{\mathrm{a}}$ & $10.3 \pm 0.17^{\mathrm{a}}$ & $0.29 \pm 0.95^{\mathrm{a}}$ \\
\hline Mopani & $61.0^{\mathrm{b}}$ & $21.2^{\mathrm{b}}$ & $32.9 \pm 0.03^{\mathrm{b}}$ & $14.6 \pm 0.15^{\mathrm{b}}$ & $18.3 \pm 0.27^{\mathrm{b}}$ & $0.27 \pm 0.38^{\mathrm{b}, \mathrm{a}}$ \\
\hline LS677 & $88.1^{\mathrm{c}}$ & $31.2^{\mathrm{c}}$ & $56.2 \pm 0.02^{\mathrm{c}}$ & $18.5 \pm 0.03^{\mathrm{c}}$ & $37.7 \pm 0.13^{\mathrm{c}}$ & $0.22 \pm 0.67^{\mathrm{c}}$ \\
\hline LS678 & $75.2^{\mathrm{d}}$ & $31.3^{\mathrm{d}, \mathrm{c}}$ & $52.3 \pm 0.02^{\mathrm{d}}$ & $19.0 \pm 0.34^{\mathrm{d}}$ & $33.2 \pm 0.97^{\mathrm{d}}$ & $0.17 \pm 1.70^{\mathrm{d}}$ \\
\hline Pan1564 & $65.0^{\mathrm{e}}$ & $32.2^{\mathrm{e}}$ & $35.7 \pm 0.05^{\mathrm{e}}$ & $14.1 \pm 0.76^{\mathrm{e}, \mathrm{b}}$ & $21.6 \pm 0.28^{\mathrm{e}}$ & $0.18 \pm 0.72^{\mathrm{e}, \mathrm{d}}$ \\
\hline Sonop & $80.2^{\mathrm{f}}$ & $21.1^{\mathrm{f}, \mathrm{b}}$ & $28.5 \pm 0.11^{\mathrm{f}}$ & $16.6 \pm 0.11^{\mathrm{f}}$ & $11.9 \pm 0.06^{\mathrm{f}}$ & $0.22 \pm 1.6^{\mathrm{ff}}$ \\
\hline
\end{tabular}

Different superscript letters within columns indicate statistical significance using ANOVA (t-test) where p-value $<0.05$ and values with similar letters are not statistically different at the same p-value.

photosystem II to photosystem I (Iqbal et al. 2019). This effect led to the decrease in chlorophyll content, especially under extreme water shortage (Table 6), followed by plants exposed to moderate water-deficit stress (Table 5). Mopani and Sonop soybeans recorded the lowest LRWC and total chlorophyll content (\%) among all the varieties. Furthermore, shortage of water in leaves and other plant parts possibly caused the production of reactive oxygen species (ROS) which changed the properties of cell membranes (Ahmad et al. 2010) and caused oxidative stress damage to chlorophyll and presumably other molecules such as DNA, lipids, and proteins that were not evaluated in this study.

The oxidative stress that was caused by limited water availability signaled the increase in the production of secondary metabolites (Table 5-6). Phenolics and flavonoids are commonly known as the largest phytochemical molecules with antioxidant properties (Sarkar and Oba 2018). These secondary metabolites were slightly increased under severe water deficit stress (Table 6) than moderate stress (Table 5) in all soybean varieties. As conjectured, the control plants expressed decreased levels of phenolic and flavonoid contents. Observations made were in contrast with findings made by Krol et al. (2014). This study reported decreased levels of phenolic acids in leaves and roots of Vitis vinifera under drought stress. Furthermore, the decreased levels of total phenolic compounds in all extracts from grapevine leaves and roots resulted in the lower antiradical activity of the samples obtained from plant parts subjected to drought stress. The study also revealed that longterm drought stress caused a decrease in the level of selected secondary metabolites based on different and specific plant tissues of the grapevine.

However, our results demonstrated high DPPH scavenging activity (Figure 2), suggesting that all extracts obtained from moderate and severe water-deficit stress contained high amounts of antioxidants as indicated in Table 5 and 6 , and therefore, possessed high antioxidant activity (Figure 2). LS677, Sonop, and LS678 recorded high antioxidant activity, including high phenol compounds under severe water-deficit stress. These observations are similar to the findings made by many authors who demonstrated that the production of secondary metabolites across species rises under abiotic stress conditions, particularly drought stress (Weidner et al. 2009; Krol et al. 2014; Mohamed and Latif 2017; Habibi 2018; Mangena 2020b).

\section{Conclusion}

According to results obtained in this study, reductions in morphological characteristics like plant height and physiological parameters such as chloroplastic pigments dramatically influence growth and productivity in crops. Therefore, these growth attributes could serve as markers in the characterization and selection of soybean varieties that are to be cultivated under low water conditions. Furthermore, improved production of secondary products such as flavonoid and phenolic content, especially under elevated water-deficit stress improved antioxidant activity that indicated reduced sensitivity of selected soybean varieties to this important abiotic stress.

\section{Acknowledgment}

Authors would like to thank the Department of Biodiversity and Department of Research Development and Administration at the University of Limpopo for their collegial support and providing with the article processing charge fee.

\section{Conflict of Interest}

Authors declare that there is no conflict of interest in publishing this paper.

\section{References}

Ahmad, P., Jaleel, C.A., Salem, M.A., Nabi, G., \& Sharma, S. (2010). Roles of enzymatic and nonenzymatic antioxidants in plants during abiotic stress. Critical Reviews in Biotechnology, 30, 161-175. 
Campillo, C., Garcia, M.I., Daza, C., \& Prieto, M.H. (2010). Study of non-destructive method for estimating the leaf area index in vegetable crops using digital images. Horti Science, 45(10), 1459-1463.

Dong, S., Jiang, Y., Dong, Y., Wang, L., et al. (2019. soybean responses to drought stress and rehydration. Saudi Journal of Biological Sciences, 26(8), 2006-2017.

Engelbrecht, G., Claasens, S., Mienie, C.M., \& Fouries, H. (2020). South Africa: An important soybean producer in sub-Saharan Africa and the quest for managing nematode pests of the crop. Agriculture, 10(6), 1-16.

Evert, R.F., \& Eichhorn, S.E. (2013). Raven Biology of Plants, $8^{\text {th }}$ Ed. W.H. Freeman and Company, New York, United States.

Habibi, G. (2018). Effects of mild and severe drought stress on the biomass, phenolic compounds production and photochemical activity of Aloe vera (L.) Burm.f. Acta Agriculture Slovenica, 111(2), 463-476.

Hussain, H.A., Hussain, S., Khaliq, A., Ashraf, U., et al. (2018). Chilling and drought stresses in crop plants: Implications, crosstalk and potential management opportunities. Frontiers in Plant Science, 9, 393. https://doi.org/10.3389/fpls.2018.00393.

Hussain, H.A., Men, S., Hussain, S., Chen, Y., et al. (2019). Interactive effects of drought and heat stresses on morphophysiological attributes, yield, nutrient uptake and oxidative status in maize hybrids. Scientific Reports, 9, 3890. https://doi.org/10.1038/s41598-019-40362-7.

Iqbal, N., Hussain, S., Raza, M.A., Yang, C.Q., et al. (2019). Drought tolerance of soybean (Glycine max L. Merr.) by improved photosynthetic characteristics and an efficient antioxidant enzyme activities under a split-root system. Frontiers in Physiology, 10, 786. https://doi.org/10.3389/fphys.2019.00786.

Król, A., Amarowicz, R., \& Weidner, S. (2014). Changes in the composition of phenolic compounds and antioxidant properties of grapevine roots and leaves (Vitis vinifera L.) under continuous of long-term drought stress. Acta Physiologiae Plantarum, 36,14911499.

Mangena, P. (2020a). Effect of hormonal seed priming on germination, growth, yield and biomass allocation in soybean grown under induced drought stress. Indian Journal of Agricultural Research, 54(5), 592-598.

Mangena, P. (2020b). Role of benzyladenine seed priming on growth and physiological and biochemical response of soybean plants growth under high salinity stress conditions. International Journal of Agronomy, ID 8847098.https://doi.org/10.1155/2020/8847098.
Mangena, P. (2021). Potential role of somatic embryo-generated synthetic seed production on mass propagation of recalcitrant grain legume crops in Sub-Saharan Africa- A review article. International Journal of Agricultural Technology, 17(3), 959-976.

Marinova, D., Ribarova, F., \& Atanassova, M. (2005). Total phenolics and total flavonoids in Bulgarian fruits and vegetables. Journal of the University of Chemical Technology and Metallurgy, 40(3), 255-260.

Mohamed, H.I., \& Latif, H.M. (2017). Improvement of drought tolerance of soybean plants by using methyl jasmonate. Physiology and Molecular Biology of Plants, 23(3), 545-556.

Odhav, B., Beckrum, S., Akula, U., \& Baijinath, H. (2007). Preliminary assessment of nutritional value of traditional leafy vegetables in KwaZulu-Natal South Africa. Journal of Food Composition and Analysis, 20, 430-435.

Patharkar, O.R., \& Walker, J.C. (2016). Core mechanisms regulating developmentally timed and environmentally triggered abscission. Plant Physiology, 172(1), 510-520.

Sarker, U., \& Oba, S. (2018). Drought stress enhances nutritional and bioactive compounds, phenolic acids and antioxidant capacity of Amaranthus leafy vegetable. BMC Plant Biology, 18, 258.

Soltys-Kalina, D., Plich, J., Stackzyk-Zyta, D., Sliwka, J., Marczewski, W. (2016). The effect of drought stress on the leaf relative water content and tuber yield of half-sib family of 'Katahdin'-derived potato cultivars. Breeding Science, 66(2), 328-331.

Taiz, L., Zeiger, E., Moller, I.M., \& Murphy, A. (2015). Plant Physiology and Development, $6^{\text {th }}$ Ed. Sinauer Associates, New York, United States.

Torres, A.M., Mau-Lastovicka, T., \& Rezaainyan, R. (1987). Total phenolics and high-performance liquid chromatography of phenolics in avocado. Journal of Agricultural and Food Chemistry, 35, 921-925.

Van Heerden, P.D.R., Kiddle, G., Pellny, T.K., Mokwala, P.W., et al. (2008). Regulation of respiration and oxygen diffusion barrier in soybean protect symbiotic nitrogen fixation from chillinginduced inhibition and shoots from premature senescence. Plant Physiology, 148,119-127.

Weidner, S., Karolak, M., Karamać, M., Kosińska, A., \& Amarowicz, R. (2009). Phenolic compounds and properties of antioxidants in grapevine roots (Vitis vinifera) under drought stress followed by regeneration. Acta Societatis Botanicorum Poloniae, 78, 97-103. 
You, J., \& Chan, Z. (2015). ROS regulation during abiotic stress Zhishen, J., Mengcheng, T., \& Jianming, W. (1999). The responses in crop plants. Frontiers in Plant Science, 6, determination of flavonoid contents in mulberry and their scavenging 1092.https://doi.org/10.3389/fpls.2015.01092. effects on superoxide radicals. Food Chemistry, 64, 555-559.

Journal of Experimental Biology and Agricultural Sciences http://www.jebas.org 